\title{
Serum concentrations of soluble interleukin 2 receptor in patients with rheumatoid arthritis: effect of second line drugs
}

\author{
Ann Crilly, Rajan Madhok, John Watson, Hilary A Capell
}

\begin{abstract}
Serum soluble interleukin 2 receptor (sIL-2R) concentrations reflect lymphocyte activation in vivo. An investigation was carried out to determine if sIL-2R concentrations correlate with existing disease activity parameters in patients with rheumatoid arthritis (RA) and whether these concentrations are modulated by treatment with second line drugs. Seventy nine patients with rheumatoid arthritis with active disease were prospectively treated with sodium aurothiomalate, auranofin, or sulphasalazine. Sequential concentrations of sIL-2R were measured by enzyme linked immunosorbent assay (ELISA). No correlations were observed between sIL-2R concentrations and clinical parameters and there were only moderate associations with concentrations of $C$ reactive protein and the erythrocyte sedimentation rate. Concentrations of sIL-2R did not significantly change with treatment. It is concluded that sIL-2R probably measures an aspect of rheumatoid synovitis distinct from acute phase reactants and is not influenced by treatment with second line drugs.
\end{abstract}

(Ann Rheum Dis 1993; 52: 58-60)

Rheumatoid synovitis is characterised by an intense inflammatory infiltrate consisting primarily of activated lymphocytes. ${ }^{1} \mathrm{~T}$ lymphocytes of the helper/inducer subset (CD4+) predominate over suppressor/cytotoxic cells $(\mathrm{CD} 8+)$ in perivascular areas, but in transitional areas CD8+ cells are more common. ${ }^{1}$ CD4+ cell activation leads to autocrine $\mathrm{T}$ cell growth in which the stimulated cells proliferate in response to their own production of the polypeptide growth factor interleukin 2 (IL-2) and the receptor for IL- $2 .^{2}$ Interleukin 2 also acts in a paracrine manner to help activate B lymphocytes and CD8+ cytotoxic $\mathrm{T}$ lymphocytes expand in number. ${ }^{2}$

Interleukin 2 binds to a high affinity receptor complex of two proteins, Tac (IL-2R $\alpha$, p55) and p75 (IL-2R $\beta)^{2}{ }^{2}$ Interleukin 2 receptor $\beta$ is expressed on activated and quiescent $T$ cells whereas IL-2R $\alpha$ is induced only after activation. ${ }^{2}$ Expression of Tac is associated with the release of a $\mathbf{4 5}$ kilodalton protein, soluble IL-2 receptor (sIL-2R). ${ }^{3}$ Although the physiological role of sIL-2R is not established it has been considered to be a reliable indicator of lymphocyte activation in vivo. ${ }^{4}$

Serum concentrations of sIL-2R have been reported to be useful in assessing and monitoring the response to treatment in a diverse range of disorders associated with immune activation and immune deficiency. ${ }^{4}$ Concentrations are also increased in the chronic autoimmune rheumatic diseases. ${ }^{3}$ In rheumatoid arthritis (RA) sIL-2R concentrations are increased and it has been suggested to be a potentially useful adjunct in monitoring disease activity, ${ }^{3}$ its value in a routine clinical setting remains to be defined, however. The aim of this study was to assess the clinical utility of serum sIL-2R concentrations in RA. We have therefore correlated concentrations with existing parameters of disease activity and also determined the effects of disease modifying drugs on serum concentrations of sIL-2R.

\section{Patients and methods}

PATIENTS

The patients included in this study were selected from two other studies: a comparative study of sulphasalazine versus auranofin ${ }^{5}$ and a long term cohort study of sodium aurothiomalate. ${ }^{6}$ All patients had RA as defined by the American Rheumatism Association and required treatment with second line drugs on clinical criteria. ${ }^{7}$ Patients with coexisting disease or receiving concomitant treatment other than non-steroidal anti-inflammatory drugs (NSAIDs) or simple analgesics were excluded. No patient had received corticosteroid treatment by mouth in the three months before entry into the study. The study drugs were administered and monitored as advised by the manufacturers.

\section{CLINICAL ASSESSMENT}

Clinical parameters evaluated included the Ritchie articular index, duration of morning stiffness in minutes, and pain rated on a $10 \mathrm{~cm}$ visual analogue scale. Functional ability was measured by the Health Assessment Questionnaire (patients treated with sodium aurothiomalate only).

\section{LABORATORY ASSESSMENT}

Laboratory indices measured included the erythrocyte sedimentation rate (ESR; Westergren), full blood and platelet count (Coulter S), and serum $C$ reactive protein measured by laser nephelometry. Serum samples obtained before and after $1 \mathrm{~g}$ of sodium aurothiomalate and 12 weeks of treatment with auranofin or sulphasalazine were stored at $-20^{\circ} \mathrm{C}$ for subsequent determination of sIL-2R concentrations. Con-

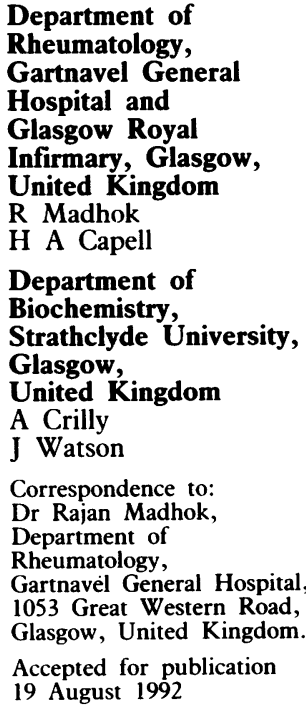


Table 1 Effect of studied drugs on clinical and laboratory parameters of disease activity. Results are mean (range)

\begin{tabular}{|c|c|c|c|c|c|c|c|c|}
\hline \multirow[t]{2}{*}{ Parameterst } & \multicolumn{2}{|l|}{ All drugs } & \multicolumn{2}{|l|}{ Auranofin } & \multicolumn{2}{|c|}{ Sodium aurothiomalate } & \multicolumn{2}{|l|}{ Sulphasalazine } \\
\hline & Before & After & Before & After & Before & After & Before & After \\
\hline $\begin{array}{l}\text { RAI } \\
\text { MS (min) } \\
\text { VAS (cm) } \\
\text { Hb (g/l) } \\
\text { WBC }\left(\times 10^{9} / \mathrm{l}\right) \\
\text { Platelets }\left(\times 10^{9} / 1\right) \\
\text { ESR (mm/hour) } \\
\text { CRP (mg/ml) } \\
\text { sIL-2R (U/ml) } \\
\text { HAQ }\end{array}$ & $\begin{array}{c}11(7-19) \\
90(30-180) \\
2 \cdot 8(1 \cdot 9-5 \cdot 5) \\
118(105-128) \\
7 \cdot 9(6 \cdot 5-9 \cdot 1) \\
407(336-489) \\
49(30-71) \\
36(16-76) \\
1100(700-1530)\end{array}$ & $\begin{array}{c}7^{*}(2-13) \\
60^{*}(10-120) \\
2 \cdot 1^{*}(1 \cdot 5-4) \\
118(109-128) \\
7 \cdot 2(6 \cdot 1-8 \cdot 9) \\
357^{*}(299-420) \\
32^{*}(20-53) \\
14^{*}(10-37) \\
1040(690-1410)\end{array}$ & $\begin{aligned} 11 & (6-19) \\
120 & (30-180) \\
5 & (2 \cdot 8-6 \cdot 5) \\
111 & (106-125) \\
8 \cdot 2(6 \cdot 5-9 \cdot 1) & (6-19-1) \\
427 & (342-487) \\
46 & (30-73) \\
49 & (20-74) \\
1190 & (700-1580)\end{aligned}$ & $\begin{array}{c}8^{*}(2-13) \\
45^{*}(5-150) \\
3^{*}(1 \cdot 8-5) \\
116(105-128) \\
7 \cdot 4(6-9 \cdot 1) \\
359^{*}(297-420) \\
36^{*}(25-58) \\
14^{*}(10-34) \\
1125(760-1720)\end{array}$ & $\begin{array}{c}12(9-18) \\
83(45-150) \\
1 \cdot 6(1 \cdot 5-2 \cdot 2) \\
119(106-131) \\
7 \cdot 9(6 \cdot 7-9) \\
392(336-483) \\
51(37-78) \\
46(24-86) \\
1120(620-1640) \\
1 \cdot 63(1 \cdot 25-2 \cdot 13)\end{array}$ & $\begin{array}{c}7^{*}(2-13) \\
60^{*}(10-90) \\
1 \cdot 4^{*}(0 \cdot 9-1 \cdot 6) \\
121(112-130) \\
6 \cdot 7(6 \cdot 4-8 \cdot 8) \\
362^{*}(296-418) \\
31^{*}(16-53) \\
14^{*}(10-37) \\
1060(690-1400) \\
1 \cdot 4(0.9-1.6)\end{array}$ & $\begin{aligned} & 10(7-19) \\
& 45(20-120) \\
& 5(4-6) \\
& 125(105-132) \\
& 7 \cdot 5(6 \cdot 2-9 \cdot 3) \\
& 384(336-530) \\
& 47(30-62) \\
& 28(13-60) \\
& 1070(748-1333)\end{aligned}$ & $\begin{array}{c}7^{*}(3-16) \\
30^{*}(10-180) \\
4^{*}(3-5 \cdot 5) \\
119(109-127) \\
7 \cdot 3(5 \cdot 5-8 \cdot 2) \\
354^{*}(296-427) \\
28^{*}(12-51) \\
135^{*}(1-23) \\
950(635-1215)\end{array}$ \\
\hline
\end{tabular}

${ }^{*} p \leqslant 0.001$; only two tailed $p$ values were taken to indicate significance using the Wilcoxon rank sum test for paired data.

†RAI=Ritchie articular index; $M S=$ morning stiffness; VAS = visual analogue scale for pain; $\mathrm{Hb}=$ haemoglobin; $W B C=$ white blood cells; ESR =erythrocyte sedimentation rate; $C R P=C$ reactive protein; sIL-2R=soluble interleukin 2 receptor; $H A Q=$ Health Assessment $Q$ uestionnaire.

trol samples matched for age and sex were obtained from a general population survey determining risk factors for coronary artery disease.

\section{SOLUBLE INTERLEUKIN 2 RECEPTOR ASSAY}

A commercially available enzyme linked immunosorbent assay (ELISA) using two noncompeting murine monoclonal antibodies to the Tac protein of the human IL-2 receptor was used (T Cell Sciences Inc, Lab-Impex, United Kingdom).

\section{STATISTICAL METHODS}

The medians and interquartile ranges (IQRs) were determined. To analyse data between two independent groups the Mann-Whitney $U$ test was used. Paired data were analysed using the Wilcoxon rank sum test. Only two tailed p values $\leqslant 0.05$ were considered significant. Associations between two variables were calculated by Spearman rank correlations. The study was approved by the hospital ethical committee.

\section{Results}

Seventy nine patients were recruited. The median patient age was 55 years (IQR 46-64) and the median disease duration was 10 years (IQR 4:5-15·5). Forty one patients received sodium aurothiomalate, 18 auranofin, and 20 sulphasalazine. The three treatment groups were comparable at the start of the study (table 1).

\section{CLINICAL DATA}

Table 1 shows the clinical findings before and after treatment. An improvement in clinical and laboratory indices of disease activity was observed with all three drugs.

\section{SOLUBLE INTERLEUKIN 2 RECEPTOR} CONCENTRATIONS

Previous studies by the manufacturer had shown that circulating rheumatoid factor does not bind non-specifically to the plate or the coating of IgG monoclonal antibody to Tac used in the ELISA. Concentrations of sIL-2R were significantly higher in patients (median 1100 ; IQR 700-1530) compared with controls (median 300; IQR 87-513) at the start of the study $(\mathrm{p}<0.001)$. In previous studies an inverse correlation with age has been shown with sIL-2R levels in normal subjects; in patients in this study there was no correlation with age $(\mathrm{r}=0.002 ; \mathrm{p}=0.8)$. Table 2 gives the correlations between sIL-2R and parameters of disease activity. No significant changes in the median values of sIL-2R were observed with any of the drugs used (table 1).

\section{Discussion}

In patients with RA the total IL-2R expression is increased on lymphocytes obtained from synovial fluid and peripheral blood. ${ }^{7}$ In addition to membrane expression of the p55 chain of IL-2R, activated $T$ cells secrete a truncated soluble form of this subunit which retains the ability to bind IL-2 with roughly the same affinity as the membrane form. ${ }^{2-4}$ The availability of a reliable, commercially available assay for this molecule provides a robust and easy method to quantify $T$ cell activation in vivo. Other workers have shown that levels are

Table 2 Correlations between initial serum soluble interleukin 2 receptor (sIL-2R) values and parameters of disease activity. Correlation coefficients calculated by Spearman rank analysis using the sIL-2R values during treatment and disease activity assessments

\begin{tabular}{|c|c|c|c|c|c|c|}
\hline & $\begin{array}{l}\text { Erythrocyte } \\
\text { sedimentation } \\
\text { rate }\end{array}$ & $\begin{array}{l}C \text { reactive } \\
\text { protein }\end{array}$ & $\begin{array}{l}\text { Ritchie } \\
\text { articular } \\
\text { index }\end{array}$ & $\begin{array}{l}\text { Duration of } \\
\text { early morning } \\
\text { stiffness }\end{array}$ & $\begin{array}{l}\text { Pain on visual } \\
\text { analogue scale }\end{array}$ & $\begin{array}{l}\text { Health } \\
\text { Assessment } \\
\text { Questionnaire }\end{array}$ \\
\hline sIL-2R & $\begin{array}{l}0.3 \\
0.008\end{array}$ & $\begin{array}{l}0.4 \\
0.0006\end{array}$ & $\begin{array}{l}0.1 \\
0.2\end{array}$ & $\begin{array}{l}0.2 \\
0.1\end{array}$ & $\begin{array}{l}0.0 \\
0.8\end{array}$ & $\begin{array}{l}0.4 \\
0.007\end{array}$ \\
\hline \multirow{4}{*}{$\begin{array}{l}\text { Erythrocyte } \\
\text { sedimentation rate } \\
\mathrm{C} \text { reactive protein }\end{array}$} & - & 0.7 & $-0 \cdot 1$ & $0 \cdot 1$ & 0.0 & $0 \cdot 2$ \\
\hline & - & 0.0001 & 0.3 & $0 \cdot 2$ & 0.6 & $0 \cdot 3$ \\
\hline & - & - & $-0 \cdot 1$ & $0 \cdot 3$ & -0.0 & $0 \cdot 4$ \\
\hline & - & - & 0.4 & 0.02 & 0.8 & 0.02 \\
\hline \multirow{2}{*}{ Ritchie articular index } & - & - & - & 0.4 & 0.2 & 0.4 \\
\hline & - & - & - & 0.0004 & $0 \cdot 1$ & 0.01 \\
\hline \multirow{4}{*}{$\begin{array}{l}\text { Duration of early } \\
\text { morning stiffness } \\
\text { Pain on visual } \\
\text { analogue scale }\end{array}$} & - & - & - & - & $0 \cdot 2$ & $0 \cdot 3$ \\
\hline & - & - & - & - & $0 \cdot 1$ & 0.05 \\
\hline & - & - & - & - & - & $0 \cdot 3$ \\
\hline & - & - & - & - & - & 0.08 \\
\hline
\end{tabular}


higher in synovial fluid from patients with RA than in serum samples, indicating that serum levels may reflect the degree of immune activation within affected joints. ${ }^{89}$

We have confirmed previous findings that levels are increased in patients with RA. ${ }^{8} 9$ The levels showed no association with clinical parameters of disease activity, however. Previous studies have provided conflicting data in this respect; Wood et al reported moderate to good correlations in 13 patients with clinical indices similar to those used in our study, ${ }^{10}$ whereas Keystone $e t a l$, in a cohort of 77 patients, found no associations using a composite clinical index of disease activity supporting our observation. ${ }^{9}$ The discrepancy between the articular index and sIL-2R levels may be due to lymphocyte infiltration of clinically unaffected joints. ${ }^{11}$ A better association might have been observed if disease activity had been scored by more sensitive indicators of articular disease such as radionuclide joint scanning. ${ }^{12}$ The moderate correlation with functional ability noted in this study needs to be further evaluated in a larger patient cohort, particularly as the association remained significant in a multivariate regression analysis (data not shown).

Some association was also observed between sIL-2R and C reactive protein and ESR, suggesting that sIL-2R is another acute phase reactant; this, however, is considered unlikely. Firstly, its biology does not suggest such a role; secondly, in this study levels did not change in the same direction as other acute phase reactants after treatment; and thirdly, levels are increased in conditions associated with a blunted acute phase response such as scleroderma. ${ }^{3}$

Clinical improvement with second line drugs in patients with RA has been noted to be associated with a significant reduction in the intensity of the $\mathrm{T}$ cell infiltrate. ${ }^{13} \mathrm{We}$, however, did not observe a change in lymphocyte activation as assessed by serum sIL-2R levels, though the clinical improvements with all three drugs were modest. These observations are not necessarily disparate as the effect on the number of $T$ cells may be due to an effect of the drugs studied on endothelial cell proliferation with a concomitant reduction in the number of blood vessels and hence on the continuing recruitment of new lymphocytes, rather than on activation. ${ }^{14}$ Alternatively, disease suppression may have not been sufficient to influence lymphocyte activation.

In conclusion, the results of this study suggest that sIL-2R probably measures an aspect of rheumatoid synovitis not readily measured by existing clinical or laboratory parameters. Furthermore, we show that this aspect of rheumatoid synovitis is probably not influenced by existing drugs.

Funded by the Arthritis and Rheumatism Council (UK) and in part by a grant from the Secretary of State's Office for Scotland.

1 Kurosaka $M$, Ziff $M$. Immunoelectron microscopic study of the distribution of $\mathrm{T}$ cell subsets in rheumatoid synovitis. thexp Med 1983; 158: 1191-210.

2 Smith K A. Interleukin 2: inception, impact and implications. Science 1988; 240: 1169-76.

3 Rubin L A. The soluble interleukin-2 receptor in rheumatic diseases. Arthritis Rheum 1990; 33: 1137-45.

4 Rubin L A, Nelson D L. The soluble interleukin-2 receptor: biology, function, and clinical application. Ann Intern Med 1990; 113: 619-27.

5 Porter D, Madhok R, Hunter J A, Capell H A. Prospective trial comparing the use of sulphasalazine and auranofin as second line drugs in patients with rheumatoid arthritis. Ann Rheum Dis 1992; 51: 461-4.

6 Porter D, Hunter J A, Capell H A. A prospective double blind comparative study of hydroxychloroquine added to patients with an inadequative response to parenteral gold therapy for rheumatoid arthritis. $\mathcal{f}$ Rheumatol. In press.

7 Arnett F C, Edworthy S M, Bloch D A, et al. The American Rheumatism Association criteria for rheumatoid arthritis. Arthritis Rheum 1980; 31: 315-24.

8 Emery P, Wood N, Gentry K, Stockman A, MacKay I R, Bernard $O$. High affinity interleukin-2 receptors in blood. Arthritis Rheum 1988; 31: 1176-81.

9 Keystone E C, Snow K M, Bombardier C, Chi-Hsing Chang, Nelson D L, Rubin L A. Elevated soluble interleukin-2 receptor levels in the sera and synovial fluids of leukin-2 receptor levels in the sera and synovial fluids of
patients with rheumatoid arthritis. Arthritis Rheum 1988; patients with 844 .

10 Wood N C, Symons J A, Duff G W. Serum interleukin-2 receptor in rheumatoid arthritis: a prognostic indicator of disease activity? I Autoimmun 1988; 1: 353-60

11 Soden M, Rooney M, Cullen A, Whelan A, Feighery C, Bresnihan B. Immunohistological features in the synovium obtained from clinically uninvolved knee joints of patients with rheumatoid arthritis. F Rheumatol 1989; 28: 287-92.

2 Mottonen T T, Hannonen P, Toivanen J, Rekonen A, Oka $M$. Value of joint scintigraphy in the prediction of erosiveness in early rheumatoid arthritis. Ann Rheum Dis
1988; 47: 183-9.

13 Rooney M, Whelan A, Feghery C, Bresnihan B. Changes in the lymphocyte infiltrate of the synovial membrane and clinical course of rheumatoid arthritis. Arthritis Rheum 1989; 32: 361-7.

14 Matsubara T, Ziff $M$. Inhibition of human endothelial cell proliferation by gold compounds. F Clin Invest 1987; 79: $1440-6$. 